\title{
Analysis of elasticity of several kinds of eggs demand in North Tapanuli Regency
}

\author{
S Nababan , S Umar, I Sembiring, Hamdan and N D Hanafi \\ Animal Production Program, Faculty of Agriculture, Universitas Sumatera Utara, \\ Medan 20155 \\ E-mail: nurzainahginting@gmail.com
}

\begin{abstract}
This study aims to determine the effect of price level on egg demand and to analyze factors affecting egg demand price in North Tapanuli regency. In addition, this study also to investigate how big the elasticity of egg demand and to know marketing channel eggs in North Tapanuli Regency. This research use survey method with consumer respondent unit and egg consumer. The sample was obtained by accidental sampling method and obtained 48 traders and 90 consumers. Data analysis was done descriptively and statistically. The results showed that the ras chicken egg and buras chicken egg are elastic while the duck eggs are inelastic. The demand for ras chicken eggs is significantly influenced by the number of dependents and substitute goods (tofu). Demand for duck eggs and buras chicken eggs is significantly influenced by the number of dependents. The more the number of family dependents then the number of egg demand will be higher. Influence of a good from the price of other goods because each item has a mutual relationship replace the function of usability, and also complement each other.
\end{abstract}

\section{Introdction}

Increase in people's income and increase in population causes an increase in animal consumption of livestock. Efforts to increase human resources are not possible without adequate nutrition. One of the livestock products that have good nutritional value is eggs. According to survey and analysis of Staistics of North Tapanuli (2015), egg consumption in North Tapanuli is $3.68 \mathrm{~kg} /$ capita / year.

Eggs are one of the animal food ingredients consumed in addition to meat, fish and milk as well as food ingredients that are very familiar with our daily lives. The nutritional content of eggs consist of: water $73,7 \%$, Protein $12,9 \%$, Fat $11,2 \%$ and Carbohydrate $0,9 \%$. and the level of fat in egg whites is almost nonexistent. Sudaryani (2003) added that almost all the fat in eggs is found in egg yolks, reaching $32 \%$, while in egg white the fat content is very small (Komala, 2008).

North Tapanuli regency is one of the marketing activities of eggs, duck eggs, and eggs from outside Tapanuli Utara regency. Traders get eggs from outside the area because not many companies laying cattle as the center of egg producers in the district. Therefore, the price of eggs has increased and the price decline is not stable. According to data obtained from the Central Bureau of Statistics of North Tapanuli Regency, egg production in North Tapanuli increased from 2013 to 2015.

The price of chicken eggs are relatively cheap, especially compared with the price of meat makes people tend to prefer chicken eggs as a fulfillment of protein consumption needs

Normatively, egg demand is determined by the price of the egg, community income, the number of dependents, and the price of other goods. The general public tends to choose goods at a cheaper price to consume an item, including eggs, because eggs are relatively cheaper than other livestock products. Generally, if a price of goods rises then the demand for the goods will decrease or vice versa. This event is called elasticity. Price changes play an important role in determining the amount of demand 
for a good. This elasticity analysis can be used to estimate the changes that will occur in egg demand in the market.

Research on the elatisitas price of eggs, duck eggs and chicken eggs in North Tapanuli regency is expected to be one of the foundations to determine policies in the livestock sub-sector for the provision of adequate food, evenly and in accordance with the nutritional needs of the population and affordable by the purchasing power of the community.

\section{Materials and Methods}

This research was conducted in several traditional markets in North Tapanuli District. The study was conducted in April 2017 - May 2017.

The method used is survey method. Surveys are the primary data collection method by providing questions to individual respondents in the form of questionnaires (Erlina, 2011).

The location of research is determined purposively in some traditional markets in North Tapanuli Regency. Traditional Market selected as research location is Tarutung Market, Siborong-borong Market, Sipahutar Market and Muara Market. The reason for choosing the research location is because the four markets have the largest market area (m2) among all traditional markets and have the largest number of traders among all traders located in the traditional market of Tapanuli Utara Regency.

\section{Results and Discussion}

The elasticity of demand is defined as a tool for measuring consumer responses to price changes. In this case, the elasticity of egg demand is seen from changes in the number of consumer demand due to the price of eggs that change every week.

\subsection{Elasticity of Chicken Race Egg Demand}

The value of egg demand elasticity of chicken eggs in North Tapanuli Regency is obtained as follows:

Tabel 1. Elastisitas Permintaan Telur Ayam Ras di Kabupaten Tapanuli Utara

\begin{tabular}{lllll}
\hline Minggu & $\begin{array}{l}\text { Harga } \\
(\text { Rp/Butir) }\end{array}$ & Jual Jumlah Permintaan (Butir) & Elastisitas & Keterangan \\
\hline I & 1232 & 14504 & & \\
II & 1316 & 14877 & 0,37 & Inelastis \\
III & 1313 & 15056 & 5,27 & Elastis \\
IV & 1314 & 15120 & 5,58 & Elastis \\
V & 1283 & 14581 & 1,51 & Elastis \\
VI & 1273 & 14873 & 2,56 & Elastis \\
VII & 1203 & 15125 & 0,30 & Inelastis \\
VIII & 1213 & 14791 & 2,65 & Elastis \\
\hline
\end{tabular}

In the table above can be seen that:

1. Changes in egg prices Rp 84 / grain in the first week to second week causes an increase in demand for eggs by 373 grains. The value of demand elasticity is 0.37 which means it is inelastic.

2. In the second and third weeks of egg price change of $\mathrm{Rp} 3$ / grain causes the increase of requested egg amounted to 179 grains. The value of elasticity of demand is 5.27 which means it is elastic.

3. In the third and fourth weeks the price of eggs increased by Rp 1 / grain causing the increase of requested eggs by 64 grains. The value of demand elasticity is 5.58 which means it is elastic.

4. In the fourth and fifth weeks of egg price increase of Rp 31 / grain, there was a decrease in the number of requests amounted to 539 grains. The elasticity value obtained is 1.51 or is elastic.

5. In the fifth and sixth weeks there was a price increase of $\mathrm{Rp} 10$ / grain causing an increase in demand of 292 grains. The elasticity value obtained is 2.56 or elastic.

6. In the sixth and seventh weeks there was a price increase of Rp 70 / grain causing egg demand to drop by 252 grains. The value of demand elasticity is 0.30 which means it is inelastic.

7. In the seventh and eighth week there was a price increase of Rp 10 / grain causing egg demand to drop by 334 grains. The value of elasticity of demand is 2.65 which means it is elastic. 


\subsection{Duck Egg Demand Elasticity}

The value of elasticity of duck egg demand in North Tapanuli Regency is as follows:

Tabel 2. Elastisitas Permintaan Telur Itik di Kabupaten Tapanuli Utara

\begin{tabular}{llllll}
\hline Minggu & $\begin{array}{l}\text { Harga } \\
(\mathrm{Rp} / \text { Butir })\end{array}$ & $\begin{array}{l}\text { Jual } \\
\text { Jumlah } \\
\text { (Butir) }\end{array}$ & Permintaan & Elastisitas & Keterangan \\
\hline I & 2512 & 638 & & \\
II & 2571 & 633 & 0,33 & Inelastis \\
III & 2546 & 602 & 5,03 & Elastis \\
IV & 2537 & 620 & 8,45 & Elastis \\
V & 2553 & 621 & 0,25 & Inelastis \\
VI & 2571 & 600 & 4,79 & Elastis \\
VII & 2606 & 592 & 0,97 & Inelastis \\
VIII & 2618 & 603 & 4,03 & Elastis \\
\hline
\end{tabular}

In the table above can be seen that:

1. Changes in egg prices Rp 59 / grain in the first week to second week causes a decrease in egg demand by 5 grains. The value of demand elasticity is 0.33 which means it is inelastic.

2. In the second and third weeks changes in egg price of Rp 25 / grain causes a decrease in the number of requested eggs by 31 grains. The value of demand elasticity is 5.03 which means it is elastic.

3. In the third and fourth weeks the price of eggs decreased by Rp 9 / grain causing an increase in the number of requested eggs by 18 grains. The value of elasticity of demand is 8.45 which means it is elastic.

4. In the fourth and fifth weeks of egg price increase of $\mathrm{Rp} 16$ / grain, there is an increase in the number of requests by 1 item. The elasticity value obtained is 0.25 or is inelastic.

5. In the fifth and sixth weeks there was a price increase of Rp 18 / grain causing a fall in demand of 21 items. The price change in the fifth week to the sixth week is elastic with a value of 4.79 .

6 . In the sixth and seventh weeks there was a price increase of Rp 35 / grain causing egg demand to fall by 8 grains. The value of demand elasticity is 0.97 which means it is inelastic.

7. In the seventh and eighth week there was a price increase of Rp 12 / grain causing egg demand to rise by 11 grains. The value of demand elasticity is 4.03 which means it is elastic.

\subsection{Elasticity of Domestic Chicken Egg Demand}

The value of elasticity of duck egg demand in North Tapanuli Regency is as follows:

Tabel 3. Elastisitas Permintaan Telur Ayam Buras di Kabupaten Tapanuli Utara

\begin{tabular}{|c|c|c|c|c|c|c|}
\hline Minggu & $\begin{array}{l}\text { Harga } \\
\text { (Rp/Butir) }\end{array}$ & Jual & $\begin{array}{l}\text { Jumlah } \\
\text { (Butir) }\end{array}$ & Permintaan & Elastisitas & Keterangan \\
\hline $\mathrm{I}$ & 2487 & & 162 & & & \\
\hline II & 2487 & & 155 & & 0 & Elastis Sempurna \\
\hline III & 2500 & & 153 & & 2,46 & Elastis \\
\hline IV & 2543 & & 159 & & 2,27 & Elastis \\
\hline $\mathrm{V}$ & 2562 & & 151 & & 6,73 & Elastis \\
\hline VI & 2568 & & 168 & & 48,07 & Elastis \\
\hline VII & 2587 & & 166 & & 1,60 & Elastis \\
\hline VIII & 2600 & & 157 & & 10,78 & Elastis \\
\hline
\end{tabular}

In the table above can be seen that:

1. Changes in egg price $\mathrm{Rp} 0$ / grain in the first week to second week causes a decrease in egg demand of 7 eggs. The value of demand elasticity of 0 which means perfectly elastic

2. In the second and third weeks of egg price change of Rp 13 / grain causing the decrease of requested egg by 2 grains. The value of elasticity of demand is 2.46 which means it is elastic. 
3. In the third and fourth weeks the price of eggs increased by Rp 43 / grains causing an increase in the number of requested eggs by 6 eggs. The value of elasticity of demand is 2.27 which means it is elastic.

4. In the fourth and fifth weeks of egg price increase of Rp 19 / grains, there was a decrease in the number of requests by 8 points. The elasticity value obtained is 6.73 or is elastic.

5. In the fifth and sixth weeks there was a price increase of $\mathrm{Rp} 6$ / grain causing a 17-point increase in demand. The elasticity value obtained is 48.07 or is elastic.

6. In the sixth and seventh weeks there is a price increase of Rp 18 / eggs causing egg demand to fall by 2 eggs. The value of demand elasticity is 1.60 which means it is inelastic.

7. In the seventh and eighth week there was a price increase of Rp 13 / grain causing egg demand to fall by 9 points. The value of demand elasticity is 10.78 which means it is elastic.

According Sukirno (2008) demand someone or something society to something goods determined many factors. Among the most important factors are as stated below:

1. Price of the goods itself

2. Prices of other goods closely related to the goods

3. Household income and average income of the community

4. The pattern of income distribution in the community

5. The taste of society

6. Population

7. Predictions about the circumstances in the future.

\subsection{Factors Affecting Number of Chicken Rats Demand}

To analyze the factors affecting the demand of eggs in North Tapanuli Regency is done by Ordinary LeastSquare (OLS) method using SPSS 16.00 program tool, from the processing the following results are obtained:

$$
\begin{aligned}
& \mathrm{Y}=14,982+2,225 \mathrm{X} 1-0,531 \mathrm{X} 2-0,465 \mathrm{X} 3-6,708 \mathrm{X} 4 \\
& \begin{array}{rllll}
\text { Signifikan } \mathrm{t} & = & (0,002) \quad(0,657) \quad(0,751) & (0,004)
\end{array}
\end{aligned}
$$

Signifikan $\mathrm{F}=0,000$

The above linear regression equation can be explained as follows:

1. The regression coefficient X1 (family dependent) is worth 2,225, it means each addition of dependent 1 person then it will cause the addition of the amount of egg demand as much as $2,225 \approx 2$ grains with assumption of other variable konstan.

2. The regression coefficient of X2 (income) is $-0,531$, meaning that any increase in income of $\mathrm{Rp}$ $1,000,000$ will cause the decrease of the number of egg demand as much as $0,531, \approx 0$ point, assuming that other variable is constant.

3. The coefficient of regression X3 (egg price) is $-0,465$, meaning that every egg price increase of Rp 100 will cause the decrease of egg demand by $0,465 \approx 0$ grain, assuming other variable is constant.

4. Regression coefficient X4 (price of other commodities / tofu) is worth -6.708 , it means that each increase of one unit know it will cause pennurunan amount of egg demand as much as 7 points with the assumption that other variables are constant.

a. Coefficient of Determination (R2)

Coefficient of determination (R2) function to see how far the ability of model in explain variation of dependent variable. Based on the results of the output shows that the value of determination coefficient (R2) of 0.720 . This means that $72 \%$ independent variation of egg price, income, dependent, and price know able to explain variation of dependent variable of egg demand, while the rest equal to $28 \%$ can be explained by variation of other independent variable not included in model.

b. Variable Significance Test Simultaneously (Test F)

The statistical test $\mathrm{F}$ basically shows whether all the independent variables included in the model as a whole have an influence on the dependent variable. From the regression results obtained value of significance $\mathrm{F}$ is $0,000(\leq 0.05)$ using $95 \%$ level $(\alpha=5 \%)$ it can be concluded that the independent variables of egg prices, income, dependents, and know simultaneously significantly affect the number of egg demand .

c. Individual Parameter Significance Test (t-Test) 
This test is done to know the significance of independent variables individually to the dependent variable. The hypothesis on $t$ test is as follows:

$\mathrm{H} 0: \beta 1=0$ (No Effect)

$\mathrm{H} 1: \beta 1 \neq 0$ (Influence)

Criteria for decision making as follows:

If probability $>0.05$, then $\mathrm{H} 0$ is accepted and $\mathrm{H} 1$ is rejected

If probability $<0.05$, then $\mathrm{H} 0$ is rejected and $\mathrm{H} 1$ is accepted

Based on the regression results obtained probability value of each variable independent, namely:

a. The number of dependents (X1): $0.002<0.05$ then H1 accepted, meaning that the amount of coverage has an effect on the actual number of egg demand.

b. Revenue (X2): $0.657>0.05$ then $\mathrm{H} 0$ is accepted, meaning the opinion does not significantly affect the number of egg demand.

c. Egg price (X3): 0.751> 0.05 then $\mathrm{H} 0$ is accepted, meaning the price of egg has no significant effect on the amount of egg demand.

d. Price know (X4): 0,004 <0,05 then $\mathrm{H} 1$ is accepted, meaning that price know have real effect to egg demand amount.

\subsection{Classic assumption test}

The result of various assumption test in this research is as

following:

a. Normality

Normality test can be seen in various ways, that is based on graphhistogram and graph of Normal P-P Plot. Based on the histogram graph in pad 2 can be seen that the data distribution is normal. Based on the graph of the Normal P-P Plot it appears that the data spreads around the diagonal line and follows the direction of the diagonal line, so it is said that the data is distributed normally.

b. Multicolinearity

The multicollinearity test can be seen based on the VIF value and the tolerance value. If VIF value $<10$, and tolerance value $>0.1$ then there is no multicollinearity. Based on regression result in appendix 2, VIF values of all variables $<10$ and tolerance value $>0,1$ can be concluded that the linear model is free from multicollinearity.

c. Heteroscedasticity

Based on SPSS output results we can see that the scatterplot chart does not form a pattern and spread so in this study data does not occur heteroskedastisitas.

Factors Affecting Number of Duck Egg Demand

To analyze the factors affecting the demand of eggs in North Tapanuli Regency is done by Ordinary LeastSquare (OLS) method using SPSS 16.00 program tool, from the processing the following results are obtained:

$$
\begin{aligned}
& \mathrm{Y}=-0,075+0,952 \mathrm{X} 1+0,193 \mathrm{X} 2+0,043 \mathrm{X} 3-0,446 \mathrm{X} 4 \\
& \text { Signifikan } \mathrm{t}=(0,000) \quad(0,390) \quad(0,918) \quad(0,195) \\
& \mathrm{R}^{2}=0,816
\end{aligned}
$$

The above linear regression equation can be explained as follows:

1. The regression coefficient X1 (family dependent) is 0.952 , it means that each addition of dependent 1 person will cause the addition of the amount of egg demand as much as $0,952 \approx 1$ item with other variable assumption constant.

2. The regression coefficient X2 (income) is 0.193 , meaning that any increase in income of Rp $1,000,000$ will cause an increase in the number of egg demand as much as $0.193 \approx 0$ grains, assuming other variables are constant.

3. The regression coefficient X3 (egg price) is 0,043 , meaning that every egg price increase of Rp 100 will cause the increase of egg demand as much as $0.043 \approx 0$ grain, assuming that other variable is constant.

4. Regression coefficient X4 (price of other commodities / tofu) is worth -0.446 , meaning that each increase of one unit of tofu will cause a decrease in the number of egg demand as much as 0 items with the assumption that other variables are constant. 
a. Coefficient of Determination (R2)

Coefficient of determination (R2) function to see how far the ability of model in explain variation of dependent variable. Based on the results of the output shows that the value of coefficient of determination (R2) of 0.81 . This means that $81 \%$ independent variation of egg price, income, dependent, and price know able to explain variation of dependent variable of egg demand, while the rest equal to $19 \%$ can be explained by variation of other independent variable not included in model.

b. Variable Significance Test Simultaneously (Test F)

From the regression results obtained the significance value of $\mathrm{F}$ is $0,000(\leq 0.05)$ using $95 \%$ level $(\alpha=$ $5 \%$ ) it can be concluded that the independent variables are the price of eggs, income, dependents, and the price of fish bloat simultaneously significantly affect the amount egg demand.

c. Individual Parameter Significance Test (t-Test)

This test is done to know the significance of independent variables individually to the dependent variable. The hypothesis on $t$ test is as follows:

H0: $\beta 1=0$ (No Effect)

$\mathrm{H} 1: \beta 1 \neq 0$ (Influence)

Criteria for decision making as follows:

If probability $>0.05$, then $\mathrm{H} 0$ is accepted and $\mathrm{H} 1$ is rejected

If probability $<0.05$, then $\mathrm{H} 0$ is rejected and $\mathrm{H} 1$ is accepted

Based on the regression results obtained probability value of each variable

independent, namely:

a. The number of dependents (X1): 0,000 $<0.05$ then $\mathrm{H} 1$ is accepted, meaning the number of dependents significantly affect the number of egg demand.

b. Revenue (X2): $0.390>0.05$ then H0 is accepted, meaning that income does not significantly affect the number of egg demand.

c. Egg price (X3): 0.918>0.05 then $\mathrm{H} 0$ is accepted, meaning the price of egg has no significant effect on the amount of egg demand.

d. Price know (X4): 0.195> 0.05 then $\mathrm{H} 0$ is accepted, meaning the price knows no real effect on the number of egg demand.

Classic assumption test

The result of various assumption test in this research is as

following:

a. Normality

Normality test can be seen in various ways, that is based on graphhistogram and graph of Normal P-P Plot. Based on the histogram graph in pad 2 can be seen that the data distribution is normal. Based on the graph of the Normal P-P Plot it appears that the data spreads around the diagonal line and follows the direction of the diagonal line, so it is said that the data is distributed normally.

b. Multicolinearity

The multicollinearity test can be seen based on the VIF value and the tolerance value. If VIF value $<10$, and tolerance value $>0.1$ then there is no multicollinearity. Based on regression result in appendix 2, VIF values of all variables $<10$ and tolerance value $>0,1$ can be concluded that the linear model is free from multicollinearity.

c. Heteroscedasticity

Based on SPSS output results we can see that the scatterplot chart does not form a pattern and spread so in this study data does not occur heteroskedastisitas

Factors Affecting Total Demand of Chicken Buras

To analyze the factors influencing the number of egg demand in North Tapanuli Regency is done by Ordinary Least Square (OLS) method using SPSS 16.00 program, from the processing the following results are obtained:

$\mathrm{Y}=13,391+1,137 \mathrm{X} 1-0,111 \mathrm{X} 2-0,442 \mathrm{X} 3-1,058 \mathrm{X} 4$

Signifikan $\mathrm{t}=(0,000) \quad(0,802) \quad(0,421) \quad(0,066)$

$\mathrm{R} 2=0,757$

Signifikan $\mathrm{F}=0,000$

The above linear regression equation can be explained as follows: 
1. The regression coefficient X1 (family dependent) is worth 1.137 , it means each addition of dependent 1 person then it will cause the addition of the number of egg demand as much as $1,137 \approx 1$ item with assumption other variable constant.

2. The regression coefficient $\mathrm{X} 2$ (income) is worth -0.111 , it means that every increase of income of Rp 1,000,000 will cause the decrease of the number of egg demand as much as $0,111 \approx 0$ item, assuming that other variable is constant.

3. The coefficient of regression $\mathrm{X} 3$ (egg price) is $-0,442$ meaning that every increase of egg price equal to Rp 100 will cause decrease of egg demand count $0,442 \approx 0$ grain, assuming other variable constant.

4. Regression coefficient X4 (price of other commodities / tofu) is worth -1.058 , meaning that each increase of one unit of tofu will cause the decrease in the number of egg demand as much as 1 point with the assumption that the other variable is constant.

a. Coefficient of Determination (R2)

Coefficient of determination (R2) function to see how far the ability of model in explain variation of dependent variable. Based on the results of the output shows that the value of coefficient of determination (R2) of 0.757 . This means that $76 \%$ variation of independent variables egg prices, income, dependent, and know able to explain variation of dependent variable of egg demand, while the rest of $24 \%$ can be explained by variation of other independent variable not included in model.

b. Variable Significance Test Simultaneously (Test F)

From the regression results obtained the significance value of $\mathrm{F}$ is $0,000(\leq 0.05)$ using $95 \%$ level $(\alpha=$ $5 \%$ ) it can be concluded that the independent variables are the price of eggs, income, dependents, and the price of fish bloat simultaneously significantly affect the amount egg demand.

c. Individual Parameter Significance Test (t-Test)

This test is done to know the significance of independent variables individually to the dependent variable. The hypothesis on $t$ test is as follows:

H0: $\beta 1=0$ (No Effect)

$\mathrm{H} 1: \beta 1 \neq 0$ (Influence)

Criteria for decision making as follows:

If probability $>0.05$, then $\mathrm{H} 0$ is accepted and $\mathrm{H} 1$ is rejected

If probability $<0.05$, then $\mathrm{H} 0$ is rejected and $\mathrm{H} 1$ is accepted

Based on the regression results obtained probability value of each variable

independent, namely:

a. The number of dependents (X1): 0,000 $<0.05$ then $\mathrm{H} 1$ is accepted, meaning the number of dependents significantly affect the number of egg demand.

b. Revenue (X2): 0.802> 0.05 then $\mathrm{H} 0$ is accepted, meaning that income has no significant effect on the number of egg demand.

c. Egg price (X3): 0,421>0,05 then H0 is accepted, meaning that egg price has no significant effect on egg demand.

d. Tofu (X4): 0,066>0,05 then $\mathrm{H} 0$ is accepted, meaning tofu no real effect to the amount of egg demand.

Classic assumption test

The result of various assumption test in this research is as

following:

a. Normality

Normality test can be seen in various ways, namely based on histogram graph and Normal P-P plot chart. Based on the histogram graph in appendix 2 it can be seen that the data distribution is normal. Based on the Normal P-P chart the plot shows that the data spreads around the diagonal line and follows the direction of the diagonal line, so it is said that the data is normally distributed.

b. Multicolinearity

The multicollinearity test can be seen based on the VIF value and the tolerance value. If VIF value $<10$, and tolerance value $>0.1$ then there is no multicollinearity. Based on regression result in appendix 2, VIF values of all variables $<10$ and tolerance value $>0,1$ can be concluded that the linear model is free from multicollinearity.

c. Heteroscedasticity 
Based on SPSS output results we can see that the scatterplot chart does not form a pattern and spread so in this study data does not occur heteroskedastisitas.

\subsection{Marketing channel}

Eggs sold to the hands of consumers require the marketing agencies involved. The marketing channel that is widely used by breeders is a long distribution channel, namely through wholesalers, middle traders and retailers. The marketing patterns used can be illustrated as follows:

1. Produsen $\longrightarrow$ Pedagang Besar $\longrightarrow$ Pedagang Pasar $\longrightarrow$ Pedagang

$\rightarrow$ EceranKonsumen Akhir

2. Produsen $\longrightarrow$ Pedagang Pasar Pedagang Eceran

3. Produsen $\longrightarrow$ Pedagang Eceran $\longrightarrow$ Nonsumen Akhir

Komen Akhir

4. Produsen $\longrightarrow$ Konsumen

The distribution channel is in accordance with Mursid (1997) suggesting that physically marketing patterns are divided into distribution channel channels, namely long distribution channels, medium distribution channels, short distribution channels and direct distribution channels.

Patterns are done so that egg products can be distributed quickly in accordance with the needs of society both in terms of time, place and usefulness of goods. Egg producers in Kabupaten Tapanuli Utara use a variety of marketing channel patterns. The use of such patterns is probably based on the resulting egg production capacity and the marketing area / area. These results are in the opinion of Kotler (1987) and Private and Irawan (1990) that large producers typically use long distribution channels because the products are produced in order to meet wider market / consumer demand and market share. It is also related to the nature of egg products which are conventional goods (convenience goods), ie goods for consumption needs that have characteristics such as the frequency of purchase is relatively frequent, and widely available, so that marketing cultivated can reach a broad consumer. On the other hand eggs including products that are high perisable so as far as possible soon to be marketed so as not to experience a lot of quality degradation.

\section{Conclusion}

The demand for chicken eggs in North Tapanuli Regency is elastic with a value of elasticity of 2.60. Demand for duck eggs in Kabupaten Tapanuli Utara is inelastic with a value of elasticity of 0.765 . Demand for chicken eggs in North Tapanuli Regency is elastic with a value of elasticity of 1.54 which means consumers are sensitive to changes in egg prices in the market.

Demand for eggs in North Tapanuli Regency is positively and significantly influenced by the number of dependents with regression coefficient value of 2.225 and also influenced negatively but significant by know with regression coefficient value of -6.708 which means that each increase of one unit of know then will cause pennurunan amount egg demand as much as 7 grains assuming another variable is constant.

Demand for duck eggs in Kabupaten Tapanuli Utara is positively and significantly influenced by the number of dependents with coefficient value of 0.952 Demand for chicken eggs in North Tapanuli Regency is influenced positively and significantly by the number of dependents. That is, every addition of 1 person's dependents will cause the addition of the number of egg demand as much as $1.137 \approx 1$ item assuming another variable is constant.

\section{References}

[1] Sudaryani dan Santoso, 1996. Pemeliharaan Ayam Ras Petelur Di Kandang Baterai. Penebar Swadaya. Jakarta.

[2] Komala, I. 2008. Kandungan GIzi Produk Peternakan. Student Master animal Science, Fac. Agriculture-UPM

[3] Sukirno, sadono. 2008. Mikro ekonomi teori pengantar. Pt Rajagrafindo persada. Jakarta.

[4] Mursid, M. 1997. Manajemen Pemasaran. Bumi Aksara, Jakarta.

[5] Kotler, P. 1987. Dasar-Dasar Pemasaran. Edisi ke- 3. Penerbit Intermedia, Jakarta. 